\title{
Analisis Kemampuan Pemecahan Masalah Matematika Siswa Ditinjau dari Gaya Kognitif Impulsif
}

\author{
Sefna Rismen ${ }^{1 *}$, Ratulani Juwita ${ }^{2}$, Uci Devinda ${ }^{3}$ \\ ${ }^{1,2,3}$ STKIP PGRI Sumatera Barat, Jalan Gunung Pangilun, Kota Padang, Sumatera Barat, Indonesia. \\ Pengiriman: 28/Oktober/2019; Diterima: 24/Maret/2020; Publikasi: 31/Maret/2020 \\ DOI: https://doi.org/10.31629/jg.v5i1.1579
}

\begin{abstract}
Abstrak
Penelitian ini dilatarbelakangi oleh rendahnya kemampuan pemecahan masalah matematis siswa serta lambatnya siswa dalam menyelesaikan masalah yang diberikan. Tujuan penelitian ini adalah untuk mendeskripsikan kemampuan pemecahan masalah matematis siswa yang memiliki gaya kognitif impulsif. Penelitian ini merupakan penelitian deskrptif kualitatif. Penentuan sampel dilakukan dengan teknik purposive sampling.Instrumen penelitian berupa tes Matching Familiar Figure Tes (MIFFT) untuk menentukan gaya kognitif impulsif, tes kemampuan pemecahan masalah, dan wawancara untuk triangulasi data. Teknik analisis data MIFFT menggunakan reduksi data, penyajian data, dan penarikan kesimpulan sedangkan teknik analisis data kemapuan pemecahan masalah menggunakan rubrik penilaian berdasarkan indikator pemecahan masalah. Hasil penelitian diperoleh kemampuan pemecahan masalah siswa yang memiliki gaya kognitif impulsif lebih dominan berada pada kriteria rendah.
\end{abstract}

Kata kunci: analisis; kemampuan pemacahan masalah; gaya kogntif impulsif

\begin{abstract}
This research is motivated by the low ability of students to solve mathematical problems and the slowness of students in solving the problems given. The purpose of this study is to describe the mathematical problems solving abilities of students who have an impulsive cognitive style. This research is a qualitative descriptive study. Sampling technique is done by purposive sampling. The research instrument is a Matching Familiar Figure Test (MIFFT) to determine the impulsive cognitive style, a problem solving ability test, and interviews for data triangulation. MIFFT data analysis techniques utilize data reduction, data presentation, and overall conclusion, meanwhile technique for data analysis for solving problems use an assessment rubric based on problem solving indicators. The research results show that impulsive student'solving ability s more dominat at low criteria.
\end{abstract}

Keywords: analisis; problem solving; impulsive cognitive style

\section{Pendahuluan}

Kemampuan pemecahan masalah matematika merupakan kemampuan matematis yang harus dikuasai oleh siswa, karena kemampuan pemecahan masalah merupakan

*Penulis Korespondensi

Email Address: $\underline{\text { syefna@gmail.com }}$

Handphone : + +62 8126726325 salah satu tujuan pembelajaran matematika. Menurut Polya dalam Hendriana.H, Rohaeti.E.E dan Sumarmo.U (2017) mengemukakan bahwa Kemampuan pemecahan masalah adalah suatu usaha mencari jalan keluar dari suatu tujuan yang 


\section{JURNAL GANTANG. Maret 2020; V(1): 61 - 68 \\ p-ISSN. 2503-0671 \\ e-ISSN. 2548-5547}

tidak begitu mudah segera dapat dicapai. Selanjutnya Ilmiyana (2018) mengemukakan kemampuan pemecahan masalah adalah kesanggupan individu dalam mencari jalan keluar dari masalah yang dahadapi tujuannya untuk memperoleh pengetahuan dan pemahaman konsep berfikir secara ilmiah. Kemampuan pemecahan masalah menurut Polya dalam Susanti (2016) adalah suatu usaha mencari jalan keluar dari suatu kesulitan, Berdasarkan pendapat di atas maka kemampuan pemecahan masalah adalah kemampuan atau kesanggupan individu untuk mencari jalan keluar dari masalah atau kesulitan yang dihadapi. Dengan demikian kemampuan pemecahan masalah penting dikuasai oleh siswa. Karena dengan belajar memecahkan masalah siswa dapat mengembangkan kemampuan membangun ide-ide dan berlatih mengintegrasikan konsep-konsep, teormateorema, dan keterampilan yang telah dipelajari (Puspita, 2016).

Namun dari beberapa hasil penelitian diperoleh bahwa kemampuan pemecahan masalah siswa masih tergolong rendah, hal ini diungkapkann oleh (Purnamasari, 2015) menunjukkan bahwa siswa yang memiliki kemampuan pemecahan masalah pada kualifikasi yang tinggi hanya $11,77 \%$, dan siswa yang memiliki kemampuan pemecahan masalah rendah dan sangat rendah sebanyak 52,94\%. Siswa mengalami kesulitan dalam memecahkan masalah yang disebabkan oleh beberapa hal diantaranya siswa kurang memahami masalah yang diberikan. sehingga mengakibatkan tahap-tahap selanjutnya seperti menyusun rencana penyelesaian, menyelesaikan masalah, dan memeriksa kembali menjadi kurang tepat. Hal ini juga terjadi di SMAN 1 Batang Anai Kabupaten Padang Pariaman, pada proses pembelajaran matematika terlihat bahwa siswa mampu menyelesaikan soal dengan bentuk yang sama dengan yang dicontohkan oleh guru, siswa terlihat kebingungan untuk menyelesaikannya, Siswa belum mampu memahami masalah dan memilih informasi dengan baik, sehingga siswa belum bisa 62 mengaitkan antara masalah yang disajikan dengan konsep materi yang dipelajari untuk menyelesaikan masalah. Maka perencanaan penyelesaian masalah menjadi tidak tepat dan mengakibatkan penyelesaian menjadi salah. Maka dapat disimpulkan bahwa kemampuan pemecahan masalah siswa belum sesuai dengan harapan.

Kemampuan pemecahan masalah dalam matematika siswa dapat dipengaruhi oleh beberapa faktor seperti intelegensi, kemampuan berfikir logis, kreativitas, gaya kognitif, kepribadian, nilai, sikap, dan minat (Ulya, 2015). Gaya kognitif merupakan bagian dari gaya belajar, gaya kognitif dapat diartikan sebagai ciri khas individual siswa dalam belajar, baik yang berkaitan dengan cara menerima dan pengolahan informasi, sikap terhadap informasi, maupun kebiasaan yang berhubungan dengan lingkungan belajar (Desmita 2010:146). Sehingga, gaya kognitif merupakan salah satu variabel dalam belajar yang harus di pertimbangkan oleh guru. Salah satu gaya kognitif yakni gaya kognitif impulsif. Dimana siswa yang memiliki gaya kognitif impulsif adalah siswa yang memiliki karakteristik cepat dalam menyelesaikan masalah, tetapi kurang cermat sehingga jawaban cenderung salah (Desmita 2010:147). Hasil penelitian yang telah dilakukan oleh (Azhil, 2017) bahwa siswa impulsif hanya $25 \%$ dapat menyelesaikan soal dengan benar. Kemudian hasil penelitian yang dilakukan oleh Warli dalam (Fadiana, 2016) siswa yang memiliki gaya kognitif impulsif dalam waktu 20 menit mampu membuat delapan gambar segi empat namun hanya dua gambar yang benar. Ini menandakan bahwa siswa impulsif cepat dalam menyelesaikan namun banyak kesalahan.

Berdasarkan uraian di atas, maka perlu dilakukan penelitian lebih lanjut tentang gaya kognitif impulsif siswa dalam menyelesaikan soal-soal pemecahan masalah.. Maka penelitian ini bertujuan untuk melihat kemampuan pemecahan masalah matematis siswa yang memiliki gaya kognitif implusif. 


\section{Metode Penelitian}

Penelitian ini dilakukan pada bulan Agustus tahun 2019. Jenis penelitian ini adalah penelitian deskriptif dengan pendekatan kualitatif. Subjek penelitian adalah kelas XII MIPA 3 SMAN 1 Batang Anai dengan pengambilan secara purposive sampling yang berjumlah 29 orang, pemilihan didasarkan pada hasil observasi dan persentase ketuntasan hasil belajar siswa yang tergolong rendah.

Instrumen penelitian yang digunakan untuk mengumpulkan data tentang gaya kognitif siswa menggunakan tes MFFT. Intrumen ini diadobsi dari MFFT yang telah dimodifikasi oleh Warli yang telah teruji validitas dan reliabilitasnya dalam Vahrum \& Rahaju (2016). MFFT ini terdiri dari 15 Soal, 2 buah soal sebagai percobaan dan 13 soal sebagai tes. Setiap soal berbentuk gambar, yang terdiri dari 2 macam gambar, yang pertama gambar standar (baku) sebanyak 1 (satu) gambar, dan kedua adalah gambar variasi (stimulus) sebanyak 8 (delapan) gambar. Tes yang ke dua berbentuk tes kemampuan pemecahan masalah yang berbentuk essay. Tes berfungsi untuk mengukur kemampuan pemecahan masalah matematis siswa. Sebelum soal diberikan terlebih dahulu dlakukan validasi soal dengan pakar dan uji coba tes .Hasil nya soal yang digunakan dalam keadaan valid dan memiliki reliabilitas 0,77 hal ini berati soal dapat dipercaya atau dapat digunakan.

Teknik analisis data pada penelitian ini menggunakan teknik analisis data yang dikemukan oleh Miles dan Huberman dalam dalam (Zulfitri, 2019) yaitu terdiri dari reduksi data, penyajian data dan penarikan kesimpulan. Data Hasil Matching Familiar Figures Test (MFFT). Data hasil MFFT dianalisis menggunakan penetapan yang dilakukan oleh Warli dalam Vahrum \& Rahaju (2016), siswa dikatakan memiliki gaya kognitif impulsive jika menyelesaikan MFFT dalam waktu $\leq 7,28$ menit dan jawaban salah $\geq 7$ soal. Data tes kemampuan pemecahan masalah dianalisis berdasarkan indikator langkah kemampuan pemecahan masalah matematika siswa. Hasil akhir tes kemampuan pemecahan masalah siswa dapat dinilai dengan skor yang diperoleh siswa dirubah kedalam skala angka (0-100). Maka nilai siswa dapat diperoleh dari

$$
\begin{aligned}
& \text { Nilai Siswa }=\frac{\text { jumlah skor yang diperoleh siswa }}{\text { jumlah skor maksimal }} \\
& \text { Selanjutnya nilai siswa dalam }
\end{aligned}
$$
penyelesaian tes kemampuan pemecahan masalah dikualifikasikan menjadi lima kriteria, yaitu tinggi, sedang, rendah, dan sangat rendah pada Tabel 1 sebagai berikut.

Tabel 1.

Kriteria kemampuan pemecahan masalah siswa

\begin{tabular}{cc}
\hline Kriteria & Nilai \\
\hline Sangat Tinggi & $81 \leq \mathrm{N} \leq 100$ \\
\hline Tinggi & $61 \leq \mathrm{N} \leq 80$ \\
\hline Sedang & $41 \leq \mathrm{N} \leq 60$ \\
\hline Rendah & $21 \leq \mathrm{N} \leq 40$ \\
\hline Sangat Rendah & $0 \leq \mathrm{N} \leq 20$ \\
\hline
\end{tabular}

Sumber: Modifikasi dari Romika \& Amalia, 2014

Kemudian dilakukan wawancara setelah siswa melaksanakan tes kemampuan pemecahan masalah. Hasil wawancara dituangkan secara tertulis dengan cara sebagai berikut; (1) mendengarkan rekaman hasil wawancara beberapa kali agar dapat menuliskan dengan tepat apa yang diucapkan responden; (2) membuat transkrip hasil wawancara; (3) memeriksa kembali transkrip hasil wawancara dengan cara mendengarkan kembali rekaman hasil wawancara.

\section{Hasil dan Pembahasan}

Berdasarkan tes MFFT yang dilakukan terhadap 29 orang siswa SMA N 1 Batang Anai, diperoleh 3 orang siswa yang memiliki gaya kognitif implusif. Dari 3 orang tersebut memiliki catatan waktu penyelesaian soal yang diberikan 5,55 menit; 4,29 menit; dan 7,17 menit, dan nilai kemampuan pemecahan masalah 55, 26, dan 21 . Hal ini jika dikategorikan 1 orang berkemampuan sedang, dan dua orang berkemampuan rendah. Jika dilihat rata-rata waktu penyelesaian masalah 
secara keseluruhan oleh siswa memakan waktu rata-rata 12 menit, hal ini menandakan siswa implusif memang cepat dalam menjawab tetapi memiliki nilai yang rendah. Analaisis hanya dilakukan pada siswa berkemampuan sedang 1 orang dan rendah 1 orang. Untuk siswa yang berkemampuan rendah diambil dari siswa yang paling cepat menyelesaikan soal.

Berikut uraian setiap pencapaian indikator kemampuan pemecahan masalah siswa impulsif.

1. Tahap memahami masalah

Pada tahap ini dilihat kemampuan siswa dalam memahami masalah, membuat diketahui dan yang ditanya dari suatu permasalahan.

Berikut gambaran jawaban siswa:

Masalah 1 :

Kamar Akbar berbentuk balok dengan ukuran $5 \mathrm{~m}$ $x 5 m \times 4 m$. Di langit-langit kamar terdapat lampu yang letaknya tepat di tengah langit-langit kamar. Pada salah satu dinding kamar dipasang saklar yang letaknya tepat di tengah-tengah dinding kamar. Hitunglah jarak saklar ke lampu pada kamar Akbar!

Hasil jawaban siswa dengan kemampuan pemecahan masalah sedang sudah dapat menuliskan apa yang diketahui dan yang ditanya, namun siswa tidak membuat garis penghubung antara titik-titik yang akan dicari. sedangkan siswa yang berkemampuan pemecahan masalah rendah langsung menuliskan diketahui langsung pada gambar tidak menuliskan apa yang ditanya dan siswa juga membuat garis penghubung titiktitik yang akan dicari. Berikut gambaran jawaban kedua siswa:

a. Siswa berkemampuan sedang

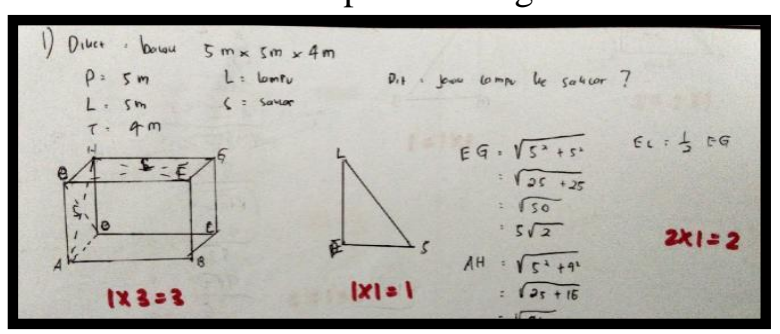

Gambar 1. Tahap memahami masalah siswa impulsif berkemampuan sedang b. Siswa berkemampuan rendah

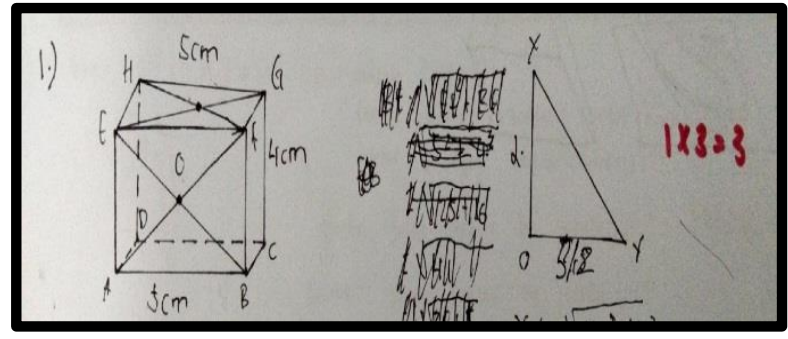

Gambar 2. Tahap memahami masalah siswa implusif berkemampuan rendah

Berdasarkan jawaban ke dua siswa di atas terlihat bahwa siswa implusif berkemampuan pemecahan masalah sedang lebih memahami permasalahan karena sudah benar membuat gambar dari soal yang ditanya yakni berbentuk balok, sedang siswa yang berkemampuan rendah membuat gambar dalam bentuk kubus. Ini terlihat kecerobohan siswa dalam memahami soal karena apabila dilihat waktu yang digunakan untuk memahami soal memang sangat cepat yakni 4,29 menit.Jika diperhatikan titik-titik sudut dari segitiga yang dibuat siswa berkemampuan rendah tertulis OXY, hal ini tidak ada dalam gambar balok yang dibuat diawal. Berdasarkan wawancara yang dilakukan hal ini diakibatkan siswa tidak paham menentukan dimana letak siku-sikunya.

\section{Tahap Menyusun Rencana Penyelesaian}

Pada tahap ini siswa dapat membuat rencana langkah-langkah penyelesaian masalah, dan memilih informasi yang tepat untuk menyelesaian masalah. Berdasarkan analisis yang dilakukan untuk kedua siswa yang berkemampuan pemecahan masalah sedang dan rendah belum membuat langkah penyelesaian masalah dan membuat gambar yang benar sesuai dengan apa yang diketahui, Namun ke dua anak implusif sudah dapat membuat gambaran penyelesaian masalah walau belum tuntas. Hal itu dapat dilihat pada kedua gambar di atas.

3. Tahap Menyelesaian Rencana Penyelesaian

Tahap ini siswa menyelesaikan permasalahan sesuai dengan rencana yang sudah dibuat dan melakukan perhitungan dengan benar. Hasil analisis jawaban siswa berkemapuan 
pemecahan masalah sedang dimana siswa sudah menyelesaikan masalah sesuai dengan rencana yang dibuat namun siswa tersebut belum dapat menyelesaikan masalah tersebut dengan baik, hal ini disebabkan karena kurang teliti dan paham untuk dalam pemisalan titik yang akan menjadi acuan dalam penyelesaian masalah. Terlihat pada kedua gambar bahwa di gambar segitiga titik titik yang digunakan untuk ketiga sudutnya adalah LES sedangkan yang dicari adalah EG dan AH sehingga siswa tidak dapat mengubungkan yang diketahui dengan yang ditanya.

4. Tahap Memeriksa Kembali

Tahap memeriksa kembali siswa melakukan pemeriksaan kembali dari penyelesaian yang telah dilakukan dan menuliskan kesimpulan apa yang didapat. Berdasarkan hasil analisis untuk ke dua siswa implusif tersebut tidak menuliskan kesimpulan yang didapat dan juga tidak selalu memeriksa kembali penyelesaian yang dilakukan. Hasil wawancara yang dilakukan siswa tersebut sudah yakin dengan apa yang dibuatnya jadi tidak perlu diperiksa lagi dan dibuat kesimpulan. Hal ini menunjukan bahwa siswa implusif memang cepat memberikan respon namun hasil yang didapat terkadang belum sesuai dengan apa yang diharapkan. Berikut jawab akhir dari kedua siswa.

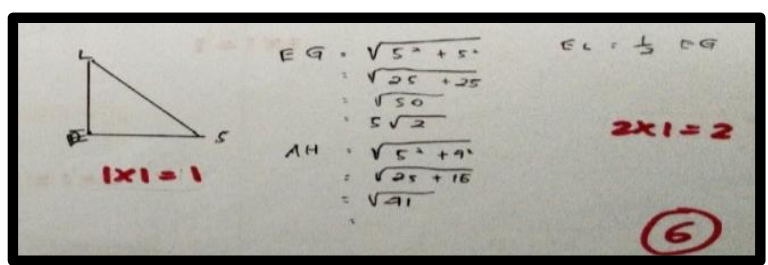

Gambar 3: Tahap menyelesaikan masalah siswa impulsif berkemapuan sedang

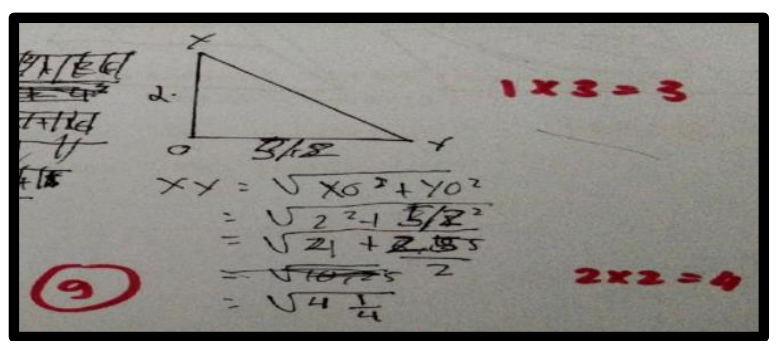

Gambar 4: Tahap menyelesaikan masalah siswa implusif berkemampuan rendah
Berdasarkan wawancara yang dilakukn kepada kedua siswa diperoleh keterangan, bahwa untuk memahami masalah siswa tersebut ada melakukan kegiatan membaca berulang-ulang kali namun tetap siswa belum mampu penyelesaian masalah dengan baik.

Berikut penyelesaian masalah 2

Pak Yahya memiliki sebuah gudang berbentuk kubus dengan panjang rusuknya $6 \mathrm{~m}$. Ia meletakkan sebuah besi pada lantai gudang, dimana panjang besi tersebut sama dengan panjang diagonal lantai gudang. Kemudian pak Yahya memasang sebuah lampu disalah satu sudut langit-langit gudang, dengan syarat lampu tidak boleh dipasang sejajar dengan ujung besi. Hitunglah jarak antara lampu ke besi pada gudang tersebut!

1. Tahap Memahami Masalah

Berikut ini adalah jawaban soal nomor 2 siswa kemampuan sedang.

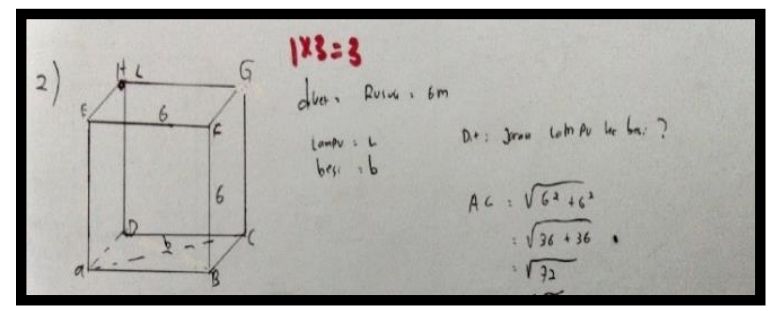

Gambar 5. Tahap memahami masalah siswa implusif berkemampuan sedang

Berdasarkan gambar 5 siswa sudah menuliskan apa yang diketahui dan yang ditanya Siswa juga menggambarkan model gudang pak yahya dengan nama $A B C D . E F G H$ dengan membuat $A C$ sebagai besi pada gudang dan memisalkan dengan $b$, sedangkan lampu yang dipilih adalah $F$.

Berikut jawaban siswa implusif dengan kemampuan rendah.

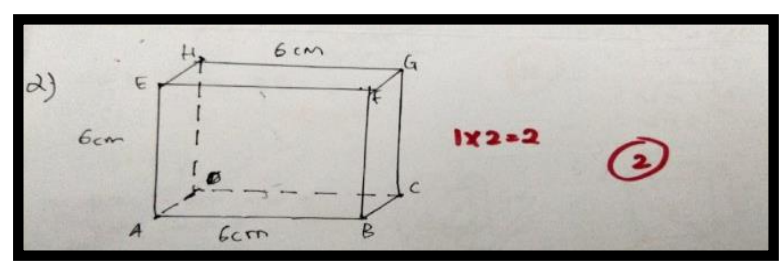

Gambar 6. Tahap memahami masalah siswa impulsif berkemampuan rendah 
Berdasarkan gambar 6, siswa sudah mencoba untuk menggambarkan model dari gudang pak Yahya, namun belum bisa menggambarkan posisi besi dengan posisi lampu yang akan dipasang dan belum paham. Jadi, disimpulkan bahwa siswa belum bisa untuk memahami masalah yang diberikan. Berdasarkan wawancara yang dilakukan siswa tidak paham dengan soal yang diberikan sehingga siswa tidak mampu menjawabnya.

2. Tahap Menyusun Rencana Penyelesaian

Untuk tahap ini siswa mencoba lagi untuk menyusun langkah-langkah penyelesaian masalah. Berikut langkah penyelesaian oleh kedua siswa implusif:

Langkah penyelesaian masalah siswa implusif berkemampuan sedang.

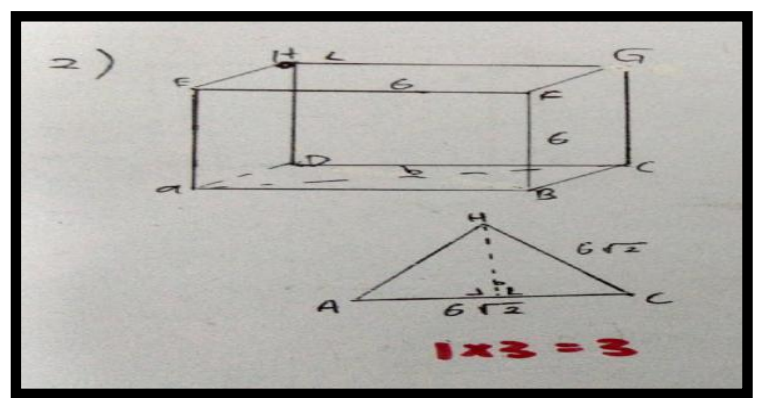

Gambar 7. Tahap menyusun rencana penyelesaian siswa impulsif sedang

Pada gambar 7 siswa sudah melakukan tahap menyusun rencana penyelesaian dengan cara mencari hubungan dari apa yang diketahui dan apa yang ditanya dari soal dengan cara membuat segitiga $H A C$. Pada segitiga $H A C$ terlihat siswa membuat titik $b$ yang terdapat pada pertengahan $A C$. Sehingga rencana yang dibuat yaitu menentukan jarak $H$ ke $b$.

Berdasarkan wawancara yang dilakukan, siswa mengatakan ada melakukan perencanaan, perencanaan yang diawali dengan menggambar kubus, dan menandai besi dengan $b$, dan lampunya pada $H$. Lalu membuat segitiga $H A C$. Siswa mengatakan langkah pertama yang dicari adalah $A C$, lalu panjang $A b$, baru dapat ditentuka $H b$. Jadi, disimpulkan siswa tersebut sudah menyusun rencanakan penyelesaian dengan baik.
Namun untuk siswa yang memiliki kemampuan pemecahan masalah rendah, tidak dapat membuat perencanaan dalam penyelesaian masalah. Berdasarkan hasil wawancara yang dilakukan siswa mengatakan bahwa untuk menyelesaikan masalah tidak tahu rumus apa yang digunakan Hal ini yang membuat kemampuan pemecahan masalah rendah.

3. Tahap Menyelesaikan Masalah

Dalam menyelesaikan masalah siswa yang memiliki kemampuan pemecahan masalah sedang, sudah melakukan langkah-langkah sesuai dengan perencanaan namun siswa belum menyelesaian dengan sempurna.

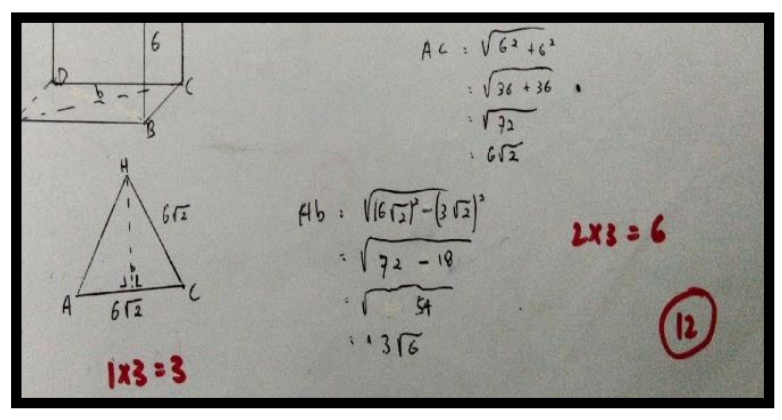

Gambar 8. Tahap menyelesaikan rencana penyelesaian siswa impulsif berkemampuan sedang

Berdasarkan gambar 8, siswa sudah melakukan tahap penyelesaian sesuai dengan rencana yang dibuat, pada lembar jawaban langkah pertama yang dibuat adalah mnentukan $A C$, lalu dilanjutkan dengan menentukan $\mathrm{Hb}$

Berdasarkan hasil wawancara yang dilakukan, siswa melakukan penyelesaian dengan langkah pertama menentukan panjang $A C$ menggunakan rumus phytagoras, dan dilanjutkan dengan menentukan $H b$ yaitu setengah dari $A C$, lalu baru dapat ditentukan panjang $H b$ dengan hasil $3 \sqrt{6}$.

Hasil analisis siswa yang memiliki kemampuan pemecahan masalah rendah, siswa tersebut tidak dapat menyelesaikan karena dari awal siswa tersebut tidak memahami persoalan. Berdasarkan wawancara yang dilakukan kepada siswa tersebut, memang dia tidak memahami permasalahan dan cara untuk menyelesaikan. 


\section{Tahap Memeriksa kembali}

Tahap memeriksa kembali merupakan bagian akhir dari tahap penyelesaian masalah, dimana siswa memeriksa kembali jawaban yang telah dibuat untuk memastikan apakah jawaban yang dibuat sudah sesuai dengan yang ditanya.

Berdasarkan wawancara yang dilakukan kepada ke dua orang siswa implusif diperoleh informasi, untuk siswa implusif yang memiliki kemampuan pemecahan masalah sedang dan rendah secara keseluruhan tidak menuliskan kesimpulan dari penyelesaian dari yang telah dikerjakan tetapi ada memeriksa kembali.

Dari uraian di atas dapat diambil kesimpulan bahwa siswa impulsif memang cepat dalam pengerjaaan soal namun jawaban yang diberikan banyak yang salah. Hal ini sesuai dengan teori yang dikemukan sebelumnya oleh (Desmita 2010:146). Bahwa siswa impulsif adalah siswa yang memiliki karakteristik cepat dalam menyelesaikan masalah, tetapi kurang cermat sehingga jawaban cenderung salah.

\section{Kesimpulan}

Siswa implusif kelas XII MIPA 3 SMA N 1 Batang Anai berjumlah 3 orang, hal ini beradasarkan tes MIFFT yang dilakukan. Kemampuan pemecahan masalah siswa berada dalam kriteria sedang 1 orang dan rendah 2 orang. Berikut kesimpulan tentang pencapaian setiap indikator kemampuan pemecahan masalah:

1. Tahap Memahami Masalah

Siswa implusif kemampuan pemecahan masalah sedang dapat memahami masalah yang diberikan dengan menuliskan apa yang diketahui dan ditanya dalam soal tersebut, namun siswa yang memiliki kemampuan pemecahan masalah rendah secara umum kurang memahami masalah dan tidak menuliskan apa yang diketahui dan ditanya dalam suatu soal.

2. Tahap Menyusun Rencana Penyelesaian

Siswa implusif dengan kemampuan pemecahan masalah sedang sudah membuat perencanaan dalam penyelesaian masalah tetapi masih kurang tepat. Siswa implusif berkemampuan pemecahan masalah rendah juga sudah membuat rencana penyelesaian tetapi masih belum jelas hubungan dengan apa yang diketahui.

3. Tahap Menyelesaikan Masalah

Penyelesaian masalah yang dilakukan sesuai dengan perencanaan yang dibuat, salah perencanaan maka salah jawaban. Hal ini terjadi untuk ke dua siswa implusif.

4. Tahap Memeriksa Kembali

Secara umum siswa implusif baik yang memiliki kemampuan pemecahan masalah sedang maupun rendah, ada melakukan pemeriksaan kembali akan tetapi tidak membuat kesimpulan. Berdasarkan wawancara yang dilakukan bahwa siswa menganggap sudah selesai menjawab soal yang diberikan.

\section{Ucapan Terimakasih}

Artikel ini merupakan hasil penelitian bersama antara dosen dan mahasiswa. Terimakasih kepada semua pihak yang telah membantu untuk penyelesaian penelitian ini.

\section{Referensi}

Azhil, I. M., Ernawati, A., \& Lutfianto, M. (2017). Profil pemecahan masalah matematika siswa ditinjau dari gaya kognitif reflektif dan impulsif, 2(1), 60-68.

Desmita. (2010).Psikologi Perkembangan Peserta Dididk. Bandung: PT remaja Rosdakarya.

Hendriana. H, Rohaeti. E.E, \&Sumarmo, U. (2015). Hard Skills dan Soft Skills Matematika Siswa. Bandung: PT Refika Aditama.

Ilmiyana, M. (2018). Analisis Kemampuan Pemecahan Masalah Matematika Siswa SMA Ditinjau Dari Tipe Kepribadian Dimensi MYER BRIGGS TYPE INDICATOR (MBTI). Universitas Islam Negri Raden Intan Lampung.

Purnamasari, P. D. (2015). Analisis kemampuan pemecahan masalah matematika siswa kelas XI SMK Muhammadiyah I Patuk pada pokok bahasan peluang. Jurnal Pendidikan Matematika dan Sains, 1(1): 1-7.

Puspita, A. Y. A. (2016). Profil pemecahan 
JURNAL GANTANG. Maret 2020; V(1): 61 - 68

p-ISSN. 2503-0671

e-ISSN. 2548-5547

masalah matematika siswa pada materi segiempat ditinjau dari gaya kognitif relektif dan implusif. Ilmiah Pendidikan Matematika, 3(5).

Susanti, Nofrianto, A., \& Mira A.(2016). Peningkatan kemampuan pemcahan masalah siswa melalui model pembelajaran laps heuristic di kelas X SMA N 2 Batang Anai. Jurnal Gantang. 1(2). 39-50 https://doi.org/10.31629/jg.v1i2.52

Vahrum, F. N., \& Rahaju, E. B. (2016). Proses Berpikir siswa SMP dalam memecahkan masalah matematika kontekstual pada materi himpunan berdasarkan gaya kognitif impulsive dan reflektif. Jurnal MATHEdunesa, 3(5).

Zulfitri, Hanifah, Aisyah, N., Indaryanti. (2019). Analisis kemampuan pemecahan masalah matematika setelah pembelajaran dengan pendekatan MEAS pada materi sistem persamaan linier tiga variabel. Jurnal Gantang, IV(1):7-14.

https://doi.org/10.31629/jg.v4i1.881 